\title{
RIFTS, OROGENS, CRATONS, AND GLOBAL TECTONICS: INTRODUCTION
}

\author{
S. V. Rasskazov ${ }^{1,2}$ \\ ${ }^{1}$ Institute of the Earth's Crust, Siberian Branch of RAS, Irkutsk, Russia \\ 2 Irkutsk State University, Irkutsk, Russia
}

\begin{abstract}
A key role in developing the Earth theory is played by comparative studies of orogens, rifts, and platforms in the equatorial, middle and high latitudes of Asia and the adjacent Arctic regions. The modern shape of the planet's triaxial asymmetrical cardioid ellipsoid results from its latest (Late Phanerozoic) geodynamic evolution that began in Arctic and then commenced in Asia. At this stage, mechanisms of the lithosphere extension and compression, combined with extension, were launched in Arctic and Asia, respectively. The special issue of Geodynamics \& Tectonophysics presents papers on this topic.
\end{abstract}

Key words: orogen; rift; Cretaceous; Cenozoic; latest geodynamic stage; Asia; Arctic; asthenosphere; lithosphere

\section{РИФТЫ, ОРОГЕНЫ, КРАТОНЫ И ГЛОБАЛЬНАЯ ТЕКТОНИКА: ВВЕДЕНИЕ В ПРОБЛЕМУ}

\author{
С. В. Рассказов ${ }^{1,2}$ \\ ${ }^{1}$ Институт земной коры СО РАН, Иркутск, Россия \\ ${ }^{2}$ Иркутский государственный университет, Иркутск, Россия
}

\begin{abstract}
Аннотация: В развитии теории Земли ключевую роль играют сравнительные исследования орогенов, рифтов и платформ в экваториальных, умеренных и высоких широтах Азии и сопредельной Арктики. Современная форма трехосного асимметричного кардиоидального эллипсоида на планете обусловлена ее новейшей (позднефанерозойской) геодинамической эволюцией, начавшейся в Арктике, а затем - в Азии. На новейшем геодинамическом этапе в Арктике был запущен механизм растяжения литосферы, в Азии - механизм сжатия, сочетающегося с растяжением. Статьи по этой тематике представлены в специальном выпуске журнала «Геодинамика и тектонофизика».
\end{abstract}

Ключевые слова: ороген; рифт; мел; кайнозой; новейший геодинамический этап; Азия; Арктика; астеносфера; литосфера

\section{RESEARCH ARTICLE}

Recommended by E.V. Sklyarov
Received: January 30, 2017

Revised: February 15, 2017

Accepted: February 20, 2017

For citation: Rasskazov S.V., 2017. Rifts, orogens, cratons, and global tectonics: Introduction. Geodynamics \& Tectonophysics 8 (1), 1-9. doi:10.5800/GT-2017-8-1-0230.

Для цитирования: Рассказов С.В. Рифты, орогены, кратоны и глобальная тектоника: введение в проблему // Геодинамика и тектонофизика. 2017. Т. 8. № 1. С. 1-9. doi:10.5800/GT-2017-8-1-0230. 


\section{1. ВВЕДЕНИЕ}

В современной кинематической теории Земли (в глобальной тектонике) древние кратонные ядра и молодые платформы континентов играют роль стабильных структурных элементов литосферы, рифты и орогены - подвижных (рис. 1).

Рифтогенез - это процесс механического и/или термального утонения океанической и континентальной литосферы, выражающийся в относительном поднятии ее нижней границы и образовании грабенов в верхней. Новейшему рифту (грабену) на земной поверхности соответствует впадина, обрамленная поднятиями горных хребтов. Полосовидная совокупность рифтовых впадин и поднятий образует рифтовую зону. Две рифтовые зоны и более, формирующиеся (по крайней мере, частично) в одно время под действием общих сил, составляют рифтовую систему.

Орогенез - это процесс сжатия литосферы, обеспечивающий ее утолщение за счет опускания нижней границы и образования горста в верхней. Новейшему орогену (горсту) на земной поверхности соответствует горный хребет с фланговыми предгорными прогибами. Полосовидная совокупность орогенов образует орогенную зону. Две орогенные зоны и более, формирующиеся (по крайней мере, частично) в одно время под действием общих сил, составляют орогенную систему.

Выяснение характера развития рифтов и орогенов, пространственно-временных соотношений между ними в структуре континентов и океанов составляет суть исследований глобальной тектоники с выходом на палеотектонические реконструкции. Рифты и орогены различаются между собой по сопутствующим процессам (магматическим, седиментационным, метаморфическим, сейсмическим, гидротермальным). Для них характерны разные полезные ископаемые. Изучение современного состояния рифтов и орогенов и их эволюции преследует цель создания моделей новейшей геодинамики, выражающей причинно-следственные связи между процессами, которые привели эволюционирующую Землю к ее современному состоянию. Некоторые аналогии с построениями новейшей геодинамики используются, достаточно условно, и в палеогеодинамических реконструкциях.

Пространственное распределение рифтов внутри континентов часто связано непосредственно с движениями и взаимодействием литосферных плит, отражающимися в эпизодической активности рифтов и их транстенсионных фрагментов, орогенов и их транспрессионных фрагментов. Иногда связь рифтов континентальной литосферы с межплитными процессами не очевидна. В работах 1960-1980-х гг. такие случаи стали объясняться растяжением литосферы под действием глубинных сил, производных всплывающих диапиров (астенолитов), а после опубликования идеи о поднятии материала с границы ядро-мантия [Morgan, 1971] случаи поверхностного выражения глубинных сил стали связываться с мантийными струями (плюмами). Рифты разделялись между собой по геометрии, кинематике и происхождению. В разное время были предложены варианты классификаций континентальных рифтовых зон с их подразделением на сводово-вулканические и щелевые (слабовулканические), «активные» и «пассивные», эпиплатформенные и эпиорогенные, окраинно-континентальные и внутриконтинентальные и т.д. [Milanovsky, 1976; Logatchev, 1977; SSengör, Natal'in, 2001]. Разнообразие систематик свидетельствовало лишь об одном - о растяжении литосферы с ее утонением в разнообразных геологических условиях.

Решение проблем строения и эволюции литосферы требует проведения мультидисциплинарных исследований современного состояния орогенов, рифтов и кратонов и предшествующей геологической истории этих структур. Текущий выпуск журнала «Геодинамика и тектонофизика» составляют статьи, подготовленные по докладам симпозиума памяти академиков РАН Н.А. Логачева и Е.Е. Милановского «Рифты, орогены и глобальная тектоника», который состоялся в рамках Сорок восьмого Тектонического совещания (МГУ, Геологический институт РАН, 2-6 февраля 2016 г.). Статьи характеризуют в основном рифтовые, орогенные и кратонные структуры Азии с выходом на рифтогенные структуры сопредельной Арктики.

\section{2. РИФТЫ, ОРОГЕНЫ И КРАТОНЫ АЗИИ}

В качестве эталонных современных континентальных рифтовых структур сначала были обозначены Восточно-Африканская и Байкальская рифтовые системы [Belousov et al., 1974; Milanovsky, 1976; Logatchev, 1977]. В рамках международных работ по проекту «Верхняя мантия», геодинамическому проекту и программе «Литосфера» в 1970-1990-х гг. изучались и другие современные рифтовые системы: Европейская, Рио-Гранде, Провинция Бассейнов и Хребтов, а также палеорифты: палеозойский Осло (Норвегия, Швеция), протерозойский Срединно-Континентальный (США) и авлакоген Южной Оклахомы (США) [Olsen, 1995]. На континентах были выделены многочисленные рифтовые структуры [Sengör, Natal'in, 2001].

Классическим выражением орогенеза на Земле считается поднятие Гималаев и Тибета во фронте Индо-Азиатского конвергентного взаимодействия. 


\section{Глобальные движения литосферных плит и блоков}

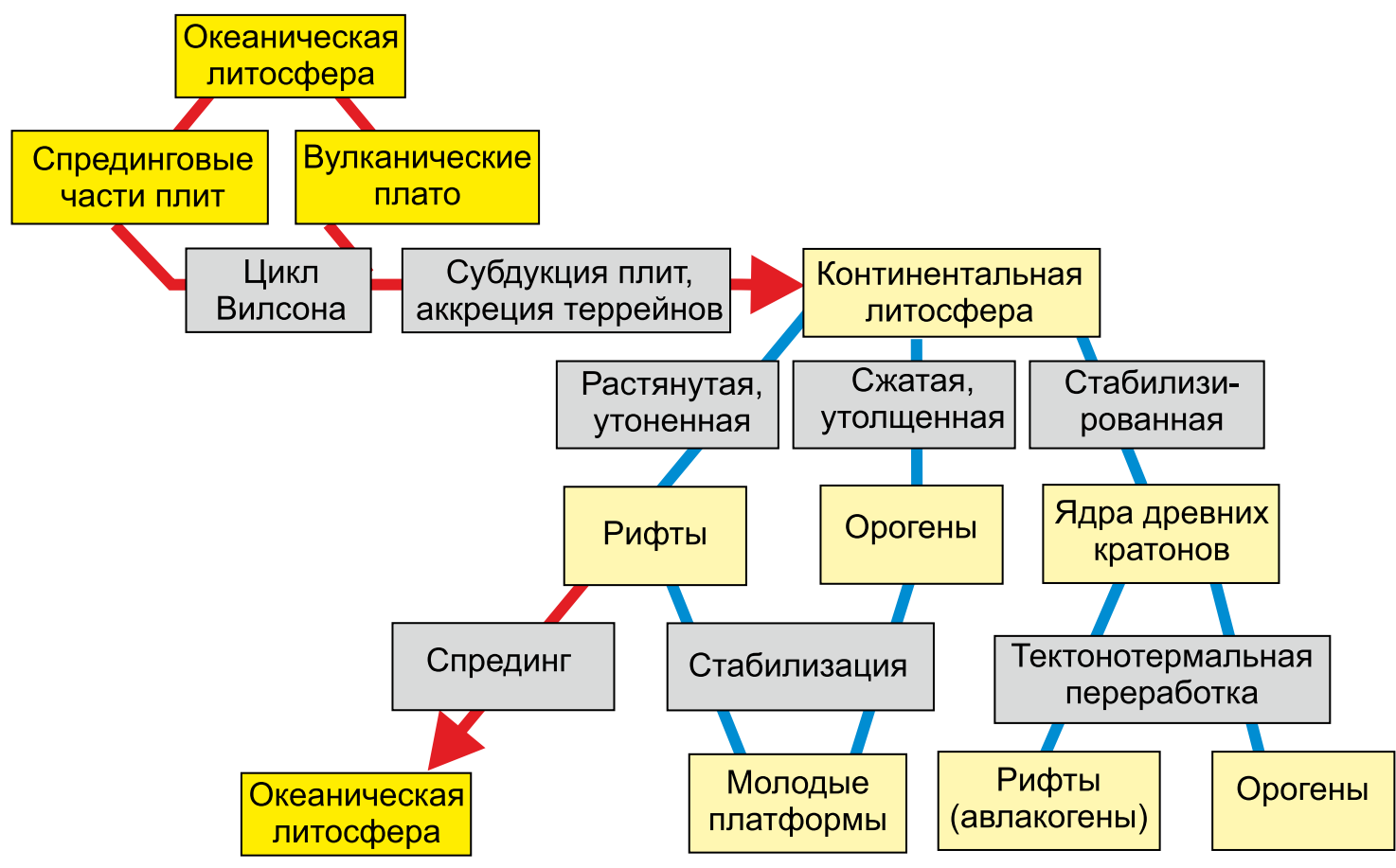

Рис. 1. Блок-диаграмма кинематической теории Земли (глобальной тектоники), демонстрирующая роль орогенов и рифтов в развитии океанической и континентальной литосферы.

Fig. 1. Flowchart of the Earth kinematical theory (global tectonics) showing the role of orogens and rifts in the development of the oceanic and continental lithosphere.

В этом орогене выделены ядерные комплексы, выдвинутые в среднем миоцене из средней коры в верхнюю в условиях растяжения, выявлены морфологические наложенные структуры растяжения верхней части коры. Такие наложенные растягивающиеся фрагменты, обозначающие распад орогена, относят к рифтам (тафрогенам) [Sengör, $\mathrm{Na-}$ tal'in, 2001].

Толщина коры и литосферы обширных областей континентов зависит от приложенных сил. При растяжении утоняется и литосфера, и кора. Если рифтогенез прогрессирует, поднятая граница Мохо и поднятая граница астеносферы и литосферы остаются взаимно согласованными до полного разрыва литосферы и спрединга. При сжатии утолщается и литосфера, и кора. В процессе утолщения нижняя часть литосферы, однако, подвергается деламинации (расслоению), а ее отслоившаяся часть тонет в мантии с проникновением астеносферного материала выше потонувшего литосферного блока. Таким образом, на продвинутой стадии орогенеза утолщенная часть литосферы нивелируется, хотя утолщенная часть коры продолжает существовать.

Пространственные соотношения процессов конвергенции и дивергенции на новейшем геодина- мическом этапе нашли яркое воплощение на территории Азии. Утолщенная кора в ее центральной части - результат сжатия на новейшем геодинамическом этапе, а утоненная кора на ее восточной окраине - результат растяжения. Под ГималайскоТибетским орогеном кора утолщена до 74 км, под восточной окраиной Азии - утонена до 25 км. Конвергентный характер новейшего взаимодействия литосферы Индостана и Азии в ее южной и центральной частях сменяется дивергентным характером процессов в Восточной и Юго-Восточной Азии, сопровождавших субдукцию под континентальную литосферу Азии океанической литосферы Пацифика. Обстановка растяжения привела к краевому нивелированию прежде существовавшей литосферы и коры орогенов, рифтов и древних кратонов (рис. 2).

В статье [Chuvashova et al., 2017] новейший геодинамический этап ограничен временным интервалом восток-юго-восточного движения литосферы Азии со встречной субдукцией литосферы Тихого океана. Развита гипотеза [Rasskazov, Chuvashova, 2016] о нарушении переходного слоя мантии нижнемантийными потоками в начале новейшего геодинамического этапа (т.е. около 90 млн лет назад) 


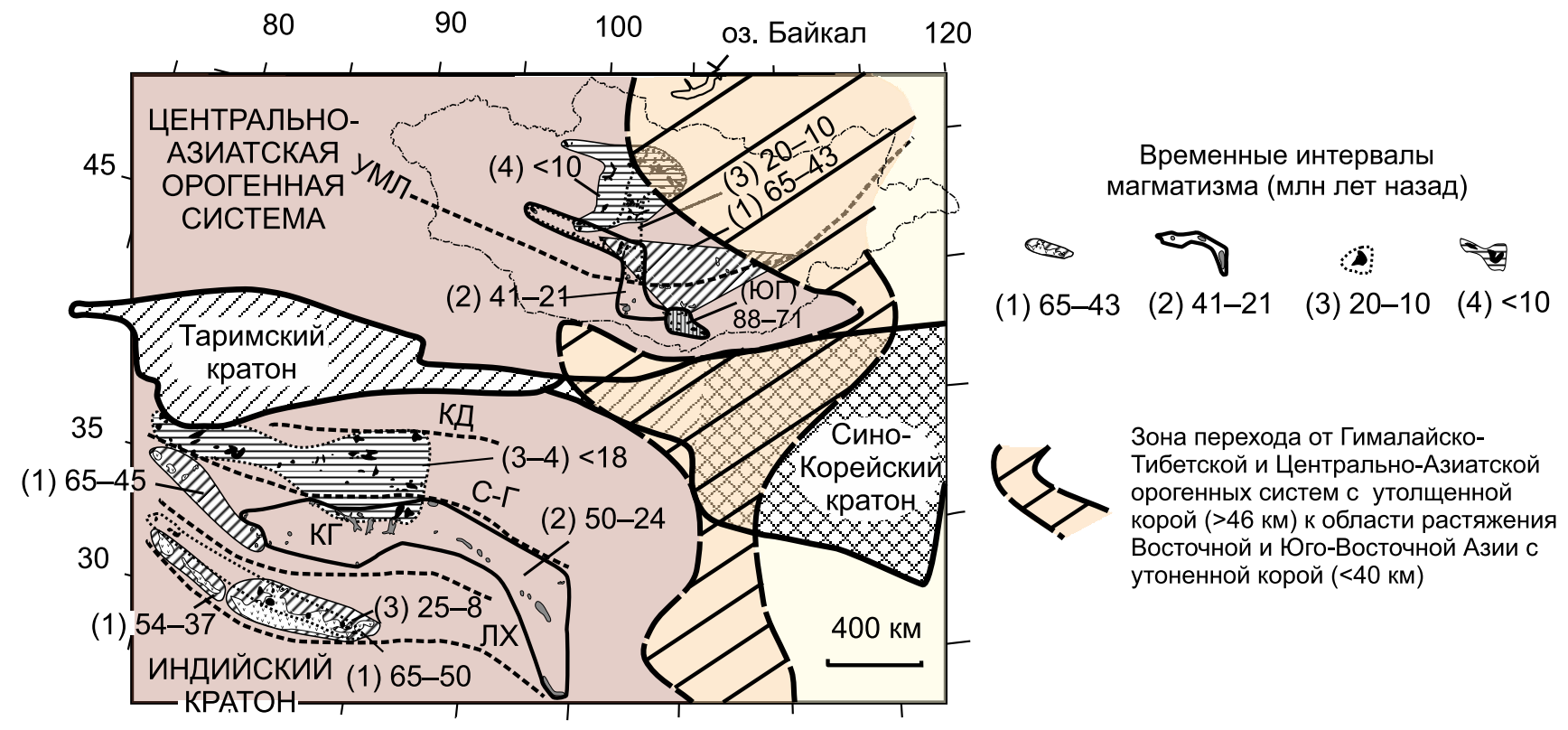

Рис. 2. Вариации толщины коры как отражение ее сжатия в Южной, Центральной Азии и растяжения в Восточной, Юго-Восточной Азии [Chuvashova, Rasskazov, 2014].

Линиями с мелкими штрихами показаны государственная граница Монголии и границы тектоно-стратиграфических террейнов плато Тибет: Лхаса (ЛХ), Кьянгтанг (КГ), Сонгпан-Ганзи (С-Г), Кайдам (КД). Дополнительные обозначения: ЮГ - ЮжноГобийский ареал позднемелового вулканизма, УМЛ - Урало-Монгольский линеамент. Пространственно-временная эволюция кайнозойского вулканизма плато Тибет согласуется с пространственно-временной эволюцией вулканизма на территории Центральной Монголии, характеризующейся утолщенной корой. Состав пород временных интервалов вулканизма: 1 - от низко- до умереннокалиевого; 2-4 - от низко- до ультракалиевого. Сильно утоненная кора на восточной окраине Азии отражает эффективное позднефанерозойское растяжение литосферы этой территории.

Fig. 2. Variations of the crust thickness as a reflection of its compression in South and Central Asia and extension in East and Southeast Asia [Chuvashova, Rasskazov, 2014].

The state border of Mongolia and the boundaries of tectono-stratigraphic terranes of the Tibetan Plateau (Lhasa, Kyangtang, SongpanGanzi, and Kaidam) are shown by dashed lines. Cyrillic letters: ЛХ - Lhasa, КГ - Kyangtang, С-Г - Songpan-Ganzi, КД - Каidam, УМЛUral-Mongolian lineament, ЮГ- South-Gobi area of Late Cretaceous volcanism. Rock compositions of volcanic time intervals: 1 - low- to moderate-K; 2-4 - low- to ultra-K. The evolution of the Cenozoic volcanism in the Tibetan Plateau in space and time is consistent with that of Central Mongolia. In the latter, the crust is thickened. At the eastern margin of Asia, the significantly thinned crust reflects the strong Late Phanerozoic extension of the lithosphere in this territory.

из-за лавинного обрушения слэбового материала, который накопился и стагнировал под закрывшимися фрагментами фанерозойских палеоокеанов: Солонкерского, Урало-Монгольского и МонголоОхотского залива Палеопацифика. Обоснована модель новейшей динамики расплавных мантийных аномалий Азии под движущейся литосферой, и введены латеральные ограничения на динамику подлитосферных потоков зонами ее конвергенции с Индостаном и Северной Америкой с обозначением особой роли Японско-Байкальского геодинамического коридора подлитосферных мантийных потоков. Сделан вывод о влиянии киля Сибирского кратона на эволюцию расплавных аномалий под движущейся литосферой как одного из глубинных геодинамических факторов.

О существовании литосферного киля толщиной порядка 200 км в кратонах в общем свидетель- ствуют проявления кимберлитов с алмазами. В статье [Konstantinov et al., 2017] приведена характеристика алмазного месторождения трубка Нюрбинская. Показано, что кимберлиты внедрились в пределах Вилюйско-Мархинского пояса среднепалеозойских трапповых даек, связанных с формированием Вилюйского палеоавлакогена. Приведенные геохронометрические и палеомагнитные данные свидетельствуют о проявлении позднесилурийской - раннедевонской эпохи кимберлито- и траппообразования.

Кратонный киль Сибири мог разрушиться в результате более позднего теплового воздействия на него глубинных мантийных процессов, выразившихся в образовании крупной Сибирской магматической провинции на рубеже палеозоя и мезозоя, около 250 млн лет назад. По данным сейсмической томографии [Koulakov, Bushenkova, 2010], какие- 
либо последствия теплового эффекта этого события в мантии под кратоном в настоящее время отсутствуют. По результатам геохронометрических работ трех последних десятилетий в позднем фанерозое выделено четыре интервала глобальной активизации кимберлитового магматизма: 1) 240215 млн лет назад, 2) 160-140 млн лет назад, 3) 105-95 млн лет назад и 4) 60-45 лет назад. Последние три интервала обозначены для Северной Америки и Якутии [Heaman et al., 2003].

В отличие от восточной части Сино-Корейского (Северо-Китайского) кратона, оказавшейся в окраинно-континентальной части утоненной литосферы Азии и характеризующейся повышенным тепловым потоком (50-105 мВт/м²) [Fan et al., 2000], Сибирский кратон не подвергся подобному прямому воздействию со стороны южной сопредельной области, проявлявшей активность в палеозое и мезозое. Его мощный литосферный киль сохранился [Rasskazov, Il'yasova, 2005]. Некоторое уменьшение толщины его литосферы в мезозое, в сравнении с толщиной палеозойской литосферы, допускалось по результатам изучения ксеногенного материала из кимберлитов северо-восточной части Сибирского кратона. Самые молодые кимберлиты эоценового возраста не содержали алмазов и могли быть производными наименее глубинных источников [Pokhilenko, Sobolev, 2008].

Характер структурных соотношений юго-восточного края Сибирского кратона с сопредельной складчатой областью рассмотрен в статье [Sankov et al., 2017]. По результатам новых геолого-структурных наблюдений в зонах разломов восточной части Иркутского амфитеатра сделан вывод о развитии здесь в палеозое надвигов, взбросов и взбросо-сдвигов под воздействием сжатия со стороны сопредельной складчатой области, а в новейшее время - в основном сбросов в условиях растяжения. В позднем кайнозое растяжение было ориентировано в направлении северо-запад - юго-восток, так же как в сопредельной структуре Байкальского рифта.

В статье [Dobrynina et al., 2017] приведены peзультаты исследований современного состояния коры юга Сибирской платформы и Саяно-Байкальской складчатой области с выделением особой роли разделяющих активных структур Байкальской рифтовой системы по параметрам затухания сейсмических волн: сейсмической добротности $\left(Q_{c}\right)$, частотному параметру $(n)$, коэффициенту затухания $(\delta)$, общему затуханию $\left(Q_{\mathrm{T}}\right)$ с оценкой вклада в общее затухание внутреннего затухания $\left(Q_{\mathrm{i}}\right)$ и затуханию вследствие рассеяния на неоднородностях среды $\left(Q_{\text {sc }}\right)$. Максимальное затухание определено в рифтовых впадинах и меньшее - в областях междувпадинных перемычек и обрамляющих горных поднятий. Показана зависимость латеральных вариаций затухания сейсмических волн от геологических и геофизических характеристик регионов и увеличение затухания с возрастанием сейсмической активности и теплового потока. Выявлены изменения значений добротности, приуроченные к скоростным границам верхней части мантии, по-

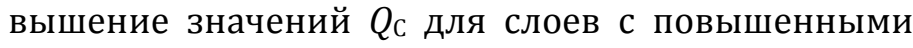
скоростями сейсмических волн и снижение значений этого параметра в слоях с низкими скоростями. По аномально повышенному затуханию сейсмических волн в районе Удоканского вулканического поля северо-восточной части Байкальской рифтовой зоны допускается возможность плавления мантии на глубинах 70-90 км. Подобные латеральные вариации параметров затухания сейсмических волн определены в рифтовых структурах Северной Танзании (Африка) и Большого Бассейна (Северная Америка).

Гипотеза об особой роли новейшей геодинамики Азии в фанерозойской эволюции Земли [Rasskazov, Chuvashova, 2016] исходит из предположения о том, что пространственное сокращение океанической коры Монголо-Охотского залива Палеопацифика сопровождалось ее погружением в переходный слой мантии с последующим обрушением накопленного материала из переходного слоя в нижнюю мантию, что и повлекло за собой запуск Северо-Забайкальской первичной расплавной аномалии переходного слоя в начале новейшего геодинамического этапа. В палеотектонической реконструкции, предложенной для позднего мезозоя Монголо-Охотского орогена [Kirillova, 2017], в качестве рифтовых охарактеризованы прогибы, окаймляющие этот ороген с севера (Зейско-Удский, или Удский) и с юга (Норско-Селемджинский).

Динамика Японско-Байкальского геодинамического коридора определялась характером субдукции Тихоокеанской плиты [Chuvashova et al., 2017], отраженной в смене состава извергавшихся вулканических продуктов, их источников и напряженнодеформированного состояния в островной дуге Северо-Восточной Японии [Jolivet et al., 1994; Sato, 1994]. Вулканические события и вариации состава вулканических пород побережья Татарского пролива были обусловлены событиями в этой дуге. Источники вулканизма межплитного типа сменялись здесь источниками внутриплитного типа. В результате такой направленной эволюции литосферы шовная зона, трассирующаяся в Татарском проливе и на о-ве Сахалин, с течением времени утратила значение межплитной границы [Rasskazov et al., 2005, 2014]. По структурным наблюдениям в Западно-Сахалинском террейне обозначена важнейшая роль правосторонних сдвиговых смещений по субмеридиональным разломам, которые, как 
предполагалось, имели место с эоцена до начала четвертичного периода [Golozubov et al., 2012, 2016]. Новые результаты структурных исследований на о-ве Сахалин, изложенные в статье [Sim et al., 2017], привели авторов к выводу о преобладании сдвигового поля неотектонических напряжений с меридиональной ориентировкой оси растяжения и широтной - оси сжатия со сменой ориентировки на Северном Сахалине на северо-восточную. В финале зафиксировано взбросовое поле напряжений. Между Западным и Восточным Сахалином не обнаружено резкого отличия ни в новейшем, ни в современном напряженном состоянии коры.

\section{3. РИФТЫ АРКТИКИ}

В сводке по рифтам мира [Sengör, Natal'in, 2001] структуры этого типа на территории Арктики не обозначались, хотя развитие Евразийского бассейна уже давно связывалось с мировой системой срединных хребтов в соединении с зоной спрединга Атлантики по трансформному разлому [Milanovsky, 1991]. Работы, выполненные в основном за последние 15 лет, показали распространение в Арктическом регионе бассейнов с тонкой корой континентального и океанического типа. Для объяснения формирования структуры региона предложены две альтернативные модели: модель Арктического плюма, в которой предполагалась его активность со средней юры до раннего (начала позднего?) мела [Khain et al., 2009; Filatova, Khain, 2009], и модель верхнемантийной ячейки, вызванной субдукцией Тихоокеанской литосферы и активной на протяжении позднего мезозоя и кайнозоя [Laverov et al., 2013].

По результатам изучения строения рифтовых систем шельфа российской части Восточной Арктики и Арктического глубоководного бассейна в 2011-2014 гг. в статье [Nikishin et al., 2017] представлена уточненная тектоническая схема региона, обоснованная сейсмическими профилями осадочного наполнения бассейнов и сделан вывод об основном этапе развития рифтовых структур в пределах морей Лаптевых, Восточно-Сибирского и Чукотского в апте-альбе. Предполагается, что до этого времени (в готериве-барреме) образовался Канадский бассейн, характеризующийся океанической литосферой, а впоследствии, в позднем мелу, продолжалось растяжение в бассейнах Подводников и Толля, в конце позднего мела и в палеоцене формировался бассейн Макарова (возможно, со спредингом) и с начала эоцена - Евразийский спрединговый бассейн. Раскрытие этого молодого бассейна, начавшееся около 56 млн лет назад, было сопряжено с раскрытием Атлантики.
Принимая апт-альбское время в качестве главного этапа рифтогенной конструкции литосферы Арктики с ее последующим развитием, мы должны связывать с этим этапом оформление трехосного асимметричного кардиоидального эллипсоида Земли [Katterfeld, 1962; Tveritinova, 2017]. Основной причиной активизации северного полярного региона в этом случае должен быть дефицит массы, образовавшийся на Северном полюсе в результате глобальных изменений в состоянии Земли как вращающегося космического объекта. Иными словами, сопутствующие процессы региона (глубинные движения в мантии, деформации литосферы и магматизм) были подчинены менявшейся форме планеты на новейшем геодинамическом этапе. Именно в это время (около 118 млн лет назад) началась меловая магнитная суперхрона, продлившаяся до 83 млн лет назад. Во временном интервале 87-85 млн лет назад Земля вошла в последнее резонансное взаимодействие ее орбиты с орбитой Марса, выраженное в седиментационных летописях великих циклов эксцентриситета (2.4 млн лет) и наклона оси вращения Земли (1.2 млн лет) [Hinnov, 2013; Ma et al., 2017].

\section{4. ЗАКЛЮЧЕНИЕ}

Чтения Н.А. Логачева и Е.Е. Милановского «Рифты, орогены и глобальная тектоника» были проведены в 2016 г. после двух симпозиумов, состоявшихся в Иркутске. Первый Всероссийский симпозиум с международным участием и молодежная школа «Кайнозойский континентальный рифтогенез», посвященный памяти Н.А. Логачева в связи с 80-летием со дня его рождения, состоялся в 2010 г., второй такой же симпозиум с молодежной школой «Континентальный рифтогенез, сопутствующие процессы» памяти Н.А. Логачева и Е.Е. Милановского - в 2013 г. Эти симпозиумы выявили дискуссионные стороны рифтовой тематики.

В ходе третьих чтений, ориентированных на вопросы, связанные с развитием кинематической и динамической теории Земли, пришло понимание ключевой роли сравнительных исследований характера эволюции орогенных, рифтовых и платформенных структур в районах экваториальной Азии, ее умеренных широт, а также ее высоких широт и сопредельной Арктики. Особо выделился переход от раннесреднефанерозойского к позднефанерозойскому (новейшему) геодинамическому этапу эволюции Земли, современная форма которой (трехосный асимметричный кардиоидальный эллипсоид) явилась отражением новейшей геодинамики. Предполагается, что толщина литосферы Азии и Арктики менялась в течение мезозоя и кай- 
нозоя. В каждом из этих регионов к литосфере были приложены единообразные усилия, обозначившие новейший геодинамический этап. В Арктике этот этап начался несколько раньше, чем в Азии.

Следующие чтения Н.А. Логачева и Е.Е. Милановского в рамках Всероссийского симпозиума с международным участием и молодежной школой «Новейший рифтогенез, орогенез и сопутствующие процессы» планируется организовать в Иркутске в 2019 г. В свете результатов будущих исследований подвижных систем литосферы требуют разрешения четыре основных вопроса, имеющих значение для понимания мезозойско-кайнозойской эволюции всей Земли: 1. Как перестроилась динамика в Тихоокеанском регионе в апте-альбе? 2. Какие конкретные объемы астеносферного слоя и в каких временных интервалах участвовали в латеральном движении материала под Азией и Арктикой? 3. В чем сходство и отличие процессов мезозойскокайнозойского рифтогенеза в Арктическом и Азиатском регионах? 4. Какую форму имела Земля до новейшего рифтогенного конструктивного этапа эволюции литосферы северного полярного региона?

\section{5. ЛИТЕРАTУРA / REFERENCES}

Belousov V.V., Gerasimovsky V.I., Goryachev A.V., Dobrovolsky V.V., Kapitsa A.P., Logatchev N.A., Milanovsky E.E., Polyakov A.I., Rykunov L.N., Sedykh V.V., 1974. East African Rift System. Vol. 1-3. Nauka, Moscow, 264 p., 260 p., 288 p. (in Russian) [Белоусов В.В., Герасимовский В.И., Горячев А.В., Добровольский В.В., Капица А.П., Логачев Н.А., Милановский Е.Е., Поляков А.И., Рыкунов Л.Н., Седых В.В. Восточно-Африканская рифтовая система. М.: Наука, 1974. T. 1.264 c.; T. 2.260 c.; T. 3.288 c.].

Chuvashova I.S., Rasskazov S.V., 2014. Magmatic Sources in the Mantle of the Evolving Earth. Irkutsk State University Publishers, Irkutsk, 291 p. (in Russian) [Чувашова И.С., Рассказов С.В. Источники магматизма в мантии эволюционирующей Земли. Иркутск: Изд-во Иркут. гос. ун-та, 2014. 291 с.].

Chuvashova I.S., Rasskazov S.V., Yi-min Sun, 2017. The latest geodynamics in Central Asia: primary and secondary mantle melting anomalies in the context of orogenesis, rifting, and lithospheric plate motions and interactions. Geodynamics \& Tectonophysics 8 (1), 45-80 (in Russian) [Чувашова И.С., Рассказов С.В., Йи-минь Сунь. Новейшая геодинамика Центральной Азии: первичные и вторичные мантийные расплавные аномалии в контексте орогенеза, рифтогенеза и движения-взаимодействия литосферных плит // Геодинамика и тектонофизика. 2017. T. 8. № 1. C. 45-80]. https://doi.org/10.5800/GT-2017-8-1-0232.

Dobrynina A.A., Sankov V.A., Déverchère J., Chechelnitsky V.V., 2017. Factors influencing seismic-wave attenuation in the lithosphere in continental rift zones. Geodynamics \& Tectonophysics 8 (1), 107-133 (in Russian) [Добрынина А.А., Саньков В.А., Девершер Ж., Чечельницкий В.В. Факторы, влияющие на затухание сейсмических волн в литосфере в зонах континентального рифтогенеза // Геодинамика и тектонофизика. 2017. т. 8. № 1. C. 107-133]. https://doi.org/10.5800/GT-2017-8-1-0234.

Fan W.M., Zhang H.F., Baker J., Jarvis K.E., Mason P.R.D., Menzies M.A., 2000. On and off the North China craton: where is the Archaean keel? Journal of Petrology 41 (7), 933-950. https://doi.org/10.1093/petrology/41.7.933.

Filatova N.I., Khain V.E., 2009. Structural units of the central arctic and their relations to the mesozoic arctic plume. Geotectonics 43 (6), 462-485. https://doi.org/10.1134/S0016852109060028.

Golozubov V.V., Kasatkin S.A., Grannik V.M., Nechayuk A.E., 2012. Deformation of the Upper Cretaceous and Cenozoic complexes of the West Sakhalin terrane. Geotectonics 46 (5), 333-351. https://doi.org/10.1134/S0016852 112050020.

Golozubov V.V., Kasatkin S.A., Malinovskii A.I., Nechayuk A.E., Grannik V.M., 2016. Dislocations of the Cretaceous and Cenozoic complexes of the northern part of the West Sakhalin Terrane. Geotectonics 50 (4), 439-452. https:// doi.org/10.1134/S0016852116040038.

Heaman L.M., Kjarsgaard B.A., Creaser R.A., 2003. The timing of kimberlite magmatism in North America: implications for global kimberlite genesis and diamond exploration. Lithos 71 (2-4), 153-184. https://doi.org/10.1016/ j.lithos.2003.07.005.

Hinnov L.A., 2013. Cyclostratigraphy and its revolutionizing applications in the Earth and planetary sciences. Geological Society of America Bulletin 125 (11-12), 1703-1734. https://doi.org/10.1130/B30934.1.

Jolivet L., Tamaki K., Fournier M., 1994. Japan Sea, opening history and mechanism: A synthesis. Journal of Geophysical Research: Solid Earth 99 (B11), 22237-22259. https://doi.org/10.1029/93JB03463.

Katterfeld G.N., 1962. Face of the Earth and Its Origin. Geografgiz, Moscow, 152 p. (in Russian) [Каттерфельд Г.Н. Лик Земли и его происхождение. М.: Географгиз, 1962. 152 с.].

Khain V.E., Filatova N.I., Polyakova I.D., 2009. Tectonics, Geodynamics and Petroleum Potential of the Eastern Arctic Seas and Their Continental Framing. Nauka, Moscow, 227 p. (in Russian] [Хаин В.Е., Филатова Н.И., Полякова И.Д. Тектоника, геодинамика и перспективы нефтегазоносности Восточно-Арктических морей и их континентального обрамления. М.: Наука, 2009. 227 с.]. 
Kirillova G.L., 2017. Late Mesozoic rifting at the flanks of the Dzhagda segment of the Mongolia-Okhotsk collisional orogen: global and regional aspects. Geodynamics \& Tectonophysics 8 (1), 171-180 (in Russian) [Кириллова Г.Л. Позднемезозойский рифтогенез на флангах Джагдинского звена Монголо-Охотского коллизионного орогена: глобальные и региональные аспекты // Геодинамика и тектонофизика. 2017. Т. 8. № 1. С. 171-180]. https://doi.org/10.5800/GT-2017-8-1-0236.

Konstantinov K.M., Yakovlev A.A., Antonova T.A., Konstantinov I.K., Ibragimov Sh.Z., Artemova E.V., 2017. Petro- and paleomagnetic characteristics of the structural-material complexes of the diamond mining of the Nyurbinskaya pipe (Middle Markha district, West Yakutia). Geodynamics \& Tectonophysics 8 (1), 135-169 (in Russian) [Константинов К.М., Яковлев А.А., Антонова Т.А., Константинов И.К., Ибрагимов Ш.З., Артемова Е.В. Петро- и палеомагнитные характеристики структурно-вещественных комплексов месторождения алмазов трубка Нюрбинская (Среднемархинский район, Западная Якутия) // Геодинамика и тектонофизика. 2017. Т. 8. № 1. C. 135-169]. https://doi.org/10.5800/GT-2017-8-1-0235.

Koulakov I., Bushenkova N., 2010. Upper mantle structure beneath the Siberian craton and surrounding areas based on regional tomographic inversion of P and PP travel times. Tectonophysics 486 (1-4), 81-100. https://doi.org/ 10.1016/j.tecto.2010.02.011.

Laverov N.P., Lobkovsky L.I., Kononov M.V., Dobretsov N.L., Vernikovsky V.A., Sokolov S.D., Shipilov E.V., 2013. A geodynamic model of the evolution of the Arctic basin and adjacent territories in the Mesozoic and Cenozoic and the outer limit of the Russian Continental Shelf. Geotectonics 47 (1), 1-30. https://doi.org/10.1134/S00168521130 10044.

Logatchev N.A., 1977. Volcanogenic and Sedimentary Formations of Rift Zones in East Africa. Nauka, Moscow, 183 p. (in Russian) [Логачев H.A. Вулканогенные и осадочные формации рифтовых зон Восточной Африки. М.: Наука, 1977. 183 с.].

Ma C., Meyers S.R., Sageman B.B., 2017. Theory of chaotic orbital variations confirmed by Cretaceous geological evidence. Nature 542 (7642), 468-470. https://doi.org/10.1038/nature21402.

Milanovsky E.E., 1976. Continental Rift Zones. Nedra, Moscow, 215 p. (in Russian) [Милановский Е.Е. Рифтовые зоны континентов. М.: Недра, 1976. 215 с.].

Milanovsky E.E., 1991. Rifting and its role in the tectonic structure of the Earth and its Mezo-Cenozoic geodynamics. Geotektonika (Geotectonics) (1), 3-20 (in Russian) [Милановский E.E. Рифтогенез и его роль в тектоническом строении Земли и ее мезокайнозойской геодинамике // Геотектоника. 1991. № 1. С. 3-20].

Morgan W.J., 1971. Convective plumes in the lower mantle. Nature 230 (5288), 42-43. https://doi.org/10.1038/ 230042a0.

Nikishin A.M., Petrov E.I., Malyshev N.A., Ershova V.P., 2017. Rift systems of the Russian eastern arctic shelf and arctic deep-water basins: link between geological history and geodynamics. Geodynamics \& Tectonophysics 8 (1), 11-43. https://doi.org/10.5800/GT-2017-8-1-0231.

Olsen K.H. (Ed.), 1995. Continental Rifts: Evolution, Structure, Tectonics / Publication No. 264 of the International Lithosphere Program. Elsevier, Amsterdam - Lausanne - New York - Oxford - Shannon - Tokyo, 511 p.

Pokhilenko N.P., Sobolev N.V., 2008. Peculiarities of the structure and evolution of the lithospheric mantle and prospects for the identification of diamondiferous kimberlites in the northeast of the Siberian platform. In: Petrology of the lithosphere and the origin of diamond. Abstracts of International Symposium dedicated to the 100th anniversary of the birth of Academician V.S. Sobolev. SB RAS Publishing House, Novosibirsk, p. 69 (in Russian) [Похuленко Н.П., Соболев Н.В. Особенности строения и эволюции литосферной мантии и перспективы выявления алмазоносных кимберлитов на северо-востоке Сибирской платформы // Петрология литосферы и происхождение алмаза: Тезисы докладов Международного симпозиума, посвященного 100-летию со дня рождения академика В.С. Соболева. Новосибирск: Изд-во СО РАН, 2008. С. 69.].

Rasskazov S.V., Chuvashova I.S., 2016. The latest geodynamics in Asia: Synthesis of data on volcanic evolution, lithosphere motion, and mantle velocities in the Baikal-Mongolian region. Geoscience Frontiers (in press). https://doi. org/10.1016/j.gsf.2016.06.009.

Rasskazov S.V., Il'yasova A.M., 2005. Phanerozoic magmatism in the Sharyzhalgai craton block and adjacent Oka zone: Comparison with magmatism in the Sino-Korean craton as tectonotype of the attenuated craton lithosphere. In: Evolution of continental lithosphere, origin of diamonds and diamond deposits. Abstracts of International Symposium dedicated to the $70^{\text {th }}$ birthday of Academician N.V. Sobolev. SB RAS Publishing House, "Geo" Branch, Novosibirsk, p. 60 (in Russian) [Рассказов С.В., Ильясова А.М. Фанерозойский магматизм Шарыжалгайского кратонного блока и сопредельной части Окинской зоны: сопоставление с магматизмом в Сино-Корейском кратоне как тектонотипе утоненной кратонной литосферы // Эволюция континентальной литосферы, происхождение алмазов и алмазных месторождений: Тезисы докладов Международного симпозиума, посвященного 70-летию со дня рождения академика Н.В. Соболева. Новосибирск: Изд-во СО РАН, филиал «Гео», 2005. C. 60].

Rasskazov S.V., Melnikov O.A., Rybin A.V., Guryanov V.A., Yasnygina T.A., Brandt I.S., Brandt S.B., Saranina E.V., Maslovskaya M.N., Fefelov N.N., Zharov A.E., 2005. The spatial change of deep sources of Cenozoic volcanic rocks on the western coast of South Sakhalin. Tikhookeanskaya Geologiya (Russian Journal of Pacific Geology) 24 (2), 10-32 (in Russian] [Рассказов С.В., Мельников О.А., Рыбин А.В., Гурьянов В.А., Ясныгина Т.А., Брандт И.С., Брандт С.Б., Саранина Е.В., Масловская М.Н., Фефелов Н.Н., Жаров А.Э. Пространственная смена глубинных источников кайнозойских вулканических пород западного побережья Южного Сахалина // Тихоокеанская геология. 2005. T. 24. № 2. C. 10-32]. 
Rasskazov S.V., Yasnygina T.A., Chuvashova I.S., 2014. Mantle sources of the cenozoic volcanic rocks of East Asia: derivatives of slabs, the sublithospheric convection, and the lithosphere. Russian Journal of Pacific Geology 8 (5), 360 378. https://doi.org/10.1134/S1819714014050030.

Sankov V.A., Parfeevets A.V., Miroshnichenko A.I., Byzov L.M., Lebedeva M.A., Sankov A.V., Dobrynina A.A., Kovalenko S.N., 2017. Late Cenozoic faulting and the stress state in the south-eastern segment of the Siberian platform. Geodynamics \& Tectonophysics 8 (1), 81-105 (in Russian) [Саньков В.А., Парфеевец А.В., Мирошниченко А.И., Бызов Л.М., Лебедева М.А., Саньков А.В., Добрынина А.А., Коваленко С.Н. Позднекайнозойское разломообразование и напряженное состояние юго-восточной части Сибирской платформы // Геодинамика и тектонофизика. 2017. T. 8. № 1. C. 81-105]. https://doi.org/10.5800/GT-2017-8-1-0233.

Sato $H_{.}, 1994$. The relationship between Late Cenozoic tectonic events and stress field and basin development in Northeast Japan. Journal of Geophysical Research: Solid Earth 99 (B11), 22261-22274. https://doi.org/10.1029/ 94JB00854.

Şengör A.M.C., Natal'in B.A., 2001. Rifts of the world. In: R.E. Ernst, K.L. Buchan (Eds.), Mantle plumes: their identification through time. Geological Society of America Special Papers, vol. 352, p. 389-482. https://doi.org/10.1130/ 0-8137-2352-3.389.

Sim L.A., Bogomolov L.M., Bryantseva G.V., Savvichev P.A., 2017. Neotectonics and tectonic stresses of the Sakhalin Island. Geodynamics \& Tectonophysics 8 (1), 181-202 (in Russian) [Сим Л.А., Богомолов Л.М., Брянцева Г.В., Саввичев П.А. Неотектоника и тектонические напряжения острова Сахалин // Геодинамика и тектонофизика 2017. T. 8. № 1. C. 181-202]. https://doi.org/10.5800/GT-2017-8-1-0237.

Tveritinova T.Yu., 2017. Geodynamic conditions of rifting on the Earth surface: problems of studying. Geodynamics \& Tectonophysics 8 (1), 203-215 (in Russian) [Тверитинова Т.Ю. Геодинамические условия процессов рифтогенеза на поверхности Земли: проблемы изучения // Геодинамика и тектонофизика. 2017. Т. 8. № 1. C. 203-215]. https://doi.org/10.5800/GT-2017-8-1-0238.

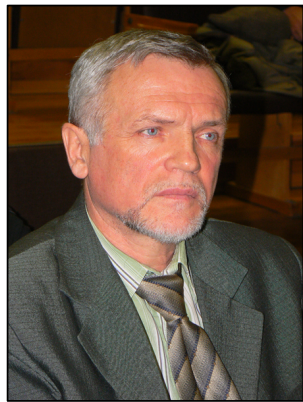

Рассказов Сергей Васильевич, докт. геол.-мин. наук, профессор, зав. лабораторией Институт земной коры СО РАН

664033, Иркутск, ул. Лермонтова, 128, Россия

Иркутский государственный университет, геологический факультет 664003, Иркутск, ул. Ленина, 3, Россия

Тел. (3952)511659; \ e-mail: rassk@crust.irk.ru

Rasskazov, Sergei V., Doctor of Geology and Mineralogy, Professor, Head of Laboratory Institute of the Earth's Crust, Siberian Branch of RAS

128 Lermontov street, Irkutsk 664033, Russia

Irkutsk State University, Geological Faculty

3 Lenin street, Irkutsk 664003, Russia

Tel. +7(3952)511659; \ e-mail: rassk@crust.irk.ru 